\title{
All Lives Matter
}

\author{
John Maszka* \\ Al Ain Men's College, GARD, United Arab Emirates
}

Submission: May 13, 2019; Published: May 21, 2019

"Corresponding author: John Maszka, Al Ain Men's College, GARD, Al Ain, Abu Dhabi, United Arab Emirates

\section{Opinion}

The past few years have been particularly dark for race relations in the U.S., and it's an incredibly sad indictment on our humanity. However, those that immediately draw the race card to explain the spate of police shootings largely ignore other facts.

It's absolutely true that African Americans comprise only 1213 percent of the population, yet they represent 24 percent of the total number of Americans that are fatally shot and killed by police. It's also true that Non-Hispanic Black males represent 3437 percent of the total U.S. correctional population.

Is this because a disproportionate percentage of African Americans are criminals? I seriously doubt it. There are obviously other issues involved. Yet, even if this were true, criminals have a right to a trial in America. So why are so many American citizens being shot and killed by police every year? This is an important question that needs to be addressed.

Is the problem a racial one? No doubt, some police officers are racist just the same as in any demographic. However, police shoot and kill a substantially larger number of White Americans every year than they do Black Americans. Complicating the matter is the race of the police officers involved in the shootings. Surely at least some of them are Black. Therefore, racism can't be the only explanation.

And so, it is with Islamic extremism. With the help of the mass media and those who benefit from the politicization of violence, many conflate mainstream Islam with Islamic extremism. But how logical can such a conclusion be? Just as most victims in police shootings in America continue to be White, the majority of victims in Islamic extremist attacks continue to be Muslim. Does this mean that Islam is a religion of both homicide and suicide? Certainly, we're capable of a more intelligent conclusion than that, aren't we? Unfortunately, logic has less to do with public perception than anger and fear.

I recently watched a debate concerning whether Muslim citizens of the EU should be allowed to remain in Europe or whether they should be forced out. This wasn't a debate about migrants, mind you-it was about citizens. More frightening still, it wasn't hosted by some crack-pot ultra-conservative talk show host. It was aired on a balanced mainstream news outlet. The fact that a significant number of people within the general population are even willing to consider such a question smacks of Jewish ghettos and the Red Scare.

To paraphrase John Locke's Letter Concerning Toleration, no one should be denied civil rights because of their religion. Locke wrote that back in 1689. More than three centuries later, do we still need to be reminded? I would add that in addition to civil rights (protection by the law), no one should be denied civil liberties (protection from the law) - for any reason-religion or otherwise.

If all of this sounds prescriptive, it's because it is. By simply settling for the status quo, we're allowing the framework of us vs. them to structure the way we view the world and everything in it. This isn't just a concern for "bleeding hearts." Nor is it strictly an attempt to defend Islam or any other religion for that matter. Islam just happens to be the greatest potential victim today. Many other groups have been targeted in the past.

So, what am I prescribing? Certainly not more violence. Rather, what I'm suggesting is that, as consumers, we hold ourselves accountable to engage in at least a minimal level of critical thinking. Stereotyping any demographic (whether Muslims or Jews or Blacks or women) is not only insensitive and wrong, it's also dangerous-and we can do better.

A personal anecdote may or may not be in order, but I'll share it anyway. My wife is Filipina, and it was probably three years into our marriage before she finally disclosed to me that most Filipinos (herself included) share the opinion that most Americans are arrogant, rude and conceited.

The only reason this information finally came out is because we were hosting a dedication for our son in the Philippines, and a disproportionately large number of people made the comment that I was "so nice!" I basically accepted the first one or two comments as compliments and didn't think anything more about it. However, after the ninth or tenth comment, I started wondering why people kept saying that I was "so nice!" Honestly, I'm not that nice. I try to be kind and considerate, but I doubt I'll win any personality contests for it. So, what was up? 
I asked my wife afterwards, and she basically told me that when all her friends and relatives heard that she married an American, they expected me to be a jerk. So now, whenever we're at a Filipino gathering or the Philippines embassy or anywhere where it's mostly Filipinos (such as Manila), I jokingly say to my wife, "So everyone here assumes that I'm an arrogant jerk?" She smiles and nods her head, "Yeah...pretty much."

I offer my personal anecdote to demonstrate that any group can be the victim of stereotyping. And while we don't hear of many Americans being attacked by Filipinos-not yet anyway (if Duterte has his way that may change) - there have been many accounts of violence between Muslims, violence between Muslims and non-Muslims, violence between Blacks and Whites and violence against women.

I'm not Muslim, Black or female (or Filipino), but my higher authority instructs me to love all people and to treat everyone with honor, respect and dignity. As a result, I'm ethically and morally responsible for the information that I simply accept as true. I'm also an academic, and as such, I'm required to think critically. This means that I should never allow the facts to be packaged for me. It also means that I must never share these prepackaged facts with others unless I'm certain that they're true.

Unfortunately, there are many prepackaged facts floating around that conflate Islamic extremism with mainstream Islam. In the words of Bernard Lewis, it's not for non-Muslims to define Islam. Only Muslims can do that. Only they can "decide what to retain of the rich and diverse inheritance of fourteen centuries of history and culture, and how to interpret that inheritance and adapt it to new needs and challenges." Our role is to ensure that nearly two billion people aren't punished for the actions of a few.

Your next submission with Juniper Publishers
will reach you the below assets
- Quality Editorial service
- Swift Peer Review
- Reprints availability
- E-prints Service
- Manuscript Podcast for convenient understanding
- Global attainment for your research
- Manuscript accessibility in different formats
( Pdf, E-pub, Full Text, Audio)
- Unceasing customer service
Track the below URL for one-step submission
https://juniperpublishers.com/online-submission.php

